\title{
Transition: A concept of significance to nursing and health care professionals
}

\author{
Nabeel Al-Yateem ${ }^{*}$ Charles Docherty \\ Department of Nursing, College of Health Sciences, University of Sharjah, Sharjah, United Arab Emirates
}

Received: December 13, 2014

Accepted: February 26, $2015 \quad$ Online Published: March 5, 2015

DOI: $10.5430 /$ jnep.v5n5p35

URL: http://dx.doi.org/10.5430/jnep.v5n5p35

\begin{abstract}
The concept of transition has growing significance within the healthcare settings. Healthcare professionals' encounters with patients and family during periods of health-illness transitions in addition to other transitions (e.g., developmental) can be significant. Therefore healthcare professionals should be aware of the meaning and the process of transition, to ensure efficient and competent provision of care. This paper will explore the concept of transition in the context of healthcare, and will suggest strategies to enable professionals to manage transition effectively.
\end{abstract}

Key Words: Transition, Children, Adolescence, Youth, Emerging adults, Health-illness Transitions, Healthcare

\section{INTRODUCTION}

Illness, particularly chronic illnesses - can be a significant burden on the life of the patient and their family, and has to be managed with a complex course of treatments, during which potentially serious complications can occur. Periods of illness are transitional by its nature, are characterised by instability and un-anticipated changes which are usually disturbing to the normal life, and can be overwhelming. ${ }^{[1-3]}$ For patients with chronic illnesses, this issue can be complicated and compounded as their illness process may extend to have no clearly defined end-point. For those chronic illnesses beginning in childhood, this may coincide with transitions that are taken place such as going to school, developing into adolescence, starting college, starting relationships, change in treatment regimen, moving to a new hospital, among many other life or illness transitions. ${ }^{[1-8]}$ Some of these transitions to adulthood have been recognized as becoming increasingly complex and diverse over the last 50 years. ${ }^{[9]}$
For patients, the periods of transitions whether short (e.g. acute illnesses) or long (e.g. chronic illnesses) can represent a time when multiple sources of distress are present, multiple needs exists, and multiple tasks (illness-related or otherwise) must be accomplished. These tasks necessarily require complex yet competent management from transition service stakeholders (patients, their families, and healthcare providers) in order to achieve the best possible outcomes in terms of patient's health and well being. It is recognized that transition can be improved through being actively managed, ${ }^{[10]}$ and models and frameworks to facilitate effective management already exist, ${ }^{[11]}$ with calls for further work in this area. ${ }^{[12]}$

Healthcare professional's encounters with patients and family have obvious significance during periods of health-illness transitions. This paper will discuss the concept of transition, arguing for its special recognition within the healthcare setting. To achieve this goal, the meaning of transition and the

\footnotetext{
*Correspondence: Nabeel Al-Yateem; Email: Nalyateem@sharjah.ac.ae; Address: Department of Nursing, College of Health Sciences, University of Sharjah, Sharjah, United Arab Emirates.
} 
process of transition will firstly be explored. This will be followed with a discussion of transition within the context of healthcare, and finally strategies to manage transition will be presented.

\section{THE MEANING OF TRANSITION}

Transition is "passing or passage from one condition, action, or place, to another" ${ }^{[13]}$ or the "development or evolution from one stage, form or style to another". ${ }^{[14]}$ The word is used in different contexts, such as in physics, chemistry, geography, music, linguistics among others. Despite the plethora of specific meanings for the term "transition", the concept almost always implies a change or movement in a particular direction, and in different levels such as the individual, family, group, organization or even societal level. ${ }^{[15-18]}$

From an anthropological point of view, Van Gennep $(1960)^{[15]}$ proposed that the idea of transition is implicit in the fact of existence so that a person's life comes to be made up of successive stages with beginnings and endings and a series of passages or transitions from one age to another and from one occupation to another.

The definitions of the transition concept within the healthcare field, do not differ significantly from definitions in other fields. Within the health literature, the concept of transition has emerged in nursing and health science over the last three decades: ${ }^{[1]}$ it refers to changes that arise in health (or illness) or development, as well as the consequent efforts of the individuals undergoing the transition to adapt and regain normality. ${ }^{[1-7]}$

At the individual level, which is arguably the most relevant for healthcare, periods of transition are characterised by disconnectedness from the individual's current social context, a transient unfamiliarity with a new surrounding environment, the emergence of new needs that must be met, and the replacement of an existing set of expectations with new ones. $^{[2-4]}$

\section{THE TRANSITION PROCESS}

The literature on transition indicates that it usually occurs as a process with different stages and with distinctive characteristics for each stage. Three phases for the transition process have been described with characteristics and features in common for each phase. ${ }^{[15,17-19]}$ The first phase involve the individual disengagement or disenchantment from the current situation, the individual or group rejects the new reality and withdraws from the first role or place and begins moving to the new role or place. However, the past role is still dominant and still no actual change in role or reality has taken place. This phase was called by the previous authors as "the separation", "ending phase", or the "impact stage", according to Silverman (1982) ${ }^{[18]}$ the individual's ability to make progress in the transition is dependent on their capacity to pass this stage.

The second phase occurs when the individual or group has left one place or state but has not yet entered the next. This phase is marked by disorientation, disintegration and discovery. This phase has been called the "liminality", ${ }^{115]}$ "neutral phase" ${ }^{[17]}$ or the "recoil/presence stage", ${ }^{[18]}$ and it is at this point, the person or group undergoes transformations that enable the entrance into the next and last phase ("incorporation", "new beginning phase", and "accommodation/selfgeneration stage"). In this last phase, the individual finds meaning to the new reality, and a new future has evolved. The individual or the group undergoing transition has the ability to enter a new and important role, place or stage in their life and they return to a state of balance. Individuals try to incorporate all the new information or ideas that they receive into new identities, and will practise the new behavioural patterns and new ways of dealing with themselves and others.

From these seminal theories therefore, it would seem that transition evokes a sense of movement towards some degree of resolution or integration following a period of instability or change which may change or transform the outcome for the individual.

\section{TYPES OF TRANSITIONS AND FACTORS THAT AFFECT IT}

It is beyond the scope of this article to discuss all types of transition and the factors that affect them in detail; however the most important ones will be explored.

The literature covering the transition process reveals four main types of transitions. These include: developmental transitions; situational transitions; health-illness transitions; and organisational transitions. These transitions may occur at all levels: societal groups, organisational, family and finally at the individual level. ${ }^{[2,20]}$ The family and individual level is the main concern for nursing and health related fields, and at this level transitions may occur in health and illness, identity, role, relationships, abilities and pattern of behaviour. ${ }^{[2,18,20]}$

Factors that can affect transition include the level of preparation and planning for the transition; the individual's knowledge; the meaning of and expectations from the transition, the environment of the individual in transition (including values and rituals of the individual or the society within which the individual is living); and finally the emotional and physical well-being of the individual undergoing transition and his/her attitudes toward this change. ${ }^{[2,18,20]}$ The mean- 
ing that a patient attaches to their transition is important, as it may change or determine the person's behaviour and responses toward that transition. What the patient believes the transition means for them, and how this might impact on their ability to carry it through, their experience of it, and its potential consequences on their health ${ }^{[2,21]}$ are all important in shaping attitudes and concepts of self-efficacy in relation to the transition. ${ }^{[22]}$

Researchers have found great emphasis placed on having appropriate knowledge and skills to help the individual during the transition experience. ${ }^{[23-26]}$ Not knowing nor understanding the process has been found to provoke stress, anxiety, and feelings of uncertainty, all capable of disrupting the transition. ${ }^{[20]}$ In addition to this, the environment, including buildings and facilities as well as social networks that surround the person undergoing the transition have been shown to be crucial. These networks include family, friends, healthcare professionals, and support groups. ${ }^{[27]}$ The existence of a supportive environment during transition can contribute positively to a sense of wellbeing and therefore enhance the transition for those who are experiencing it. These findings have been supported by a number of other researchers who have warned that the absence or lack of such support during transition may leave the person lost, with negative emotions of powerlessness, confusion, frustration and conflict. ${ }^{[18,23,28]}$ Maintaining the emotional and physical well-being of the individual are important factors during the transition. ${ }^{[20,23,27]}$ If these aspects of the individual go unrecognised, they can interrupt the assimilation of new information during the transition process and negatively affect the whole process.

Finally the level of planning will determine how easy and smooth the transition process can be. Kerfoot $(1988)^{[29]}$ suggested that good planning can contribute to an uneventful and less stressful transition. Transition planning should include identifying the key personnel involved and any potential problems or issues that might arise in the context of initiating an effective communication network between them in order to co-ordinate transition efforts. ${ }^{[25,26]}$

\section{MANAGED VERSUS NON-MANAGED TRAN- SITION}

Poorly managed transition processes have been shown to have a negative effect on the patient undergoing transition, their health, and their treatment objectives and outcomes. ${ }^{[22,30-32]}$ Examples of these negative effects include unnecessary extra anxiety and stress ${ }^{[8]}$ decreased utilization of health care facilities, ${ }^{[32]}$ non-compliance with treatment and increased complications, ${ }^{[31]}$ and finally avoidable death especially in life threatening illnesses such as cardiac dis- eases. $^{[30]}$

In contrast there is emerging evidence that well-organised health care during transition periods, do have measurable benefits for young people and their families. ${ }^{[33-37]}$ In these studies, the introduction of improved interventions targeting the transition period in patients' lives resulted in benefits for patients. These included more satisfaction with care, more effective transitions, patients better prepared to carry out transitions, and fewer non-attendances at clinics throughout transition. Indeed patients receiving a well-managed transition were more service engaged and proactive, had fewer hospital admissions or re-admissions, and had fewer health complications in the post transition period.

\section{AdDRESSING TRANSITION PHENOMENA IN HEALTHCARE SETTINGS}

To assist healthcare professionals manage the transition periods in patients life's effectively, theoretical models and components of transition care have been outlined in the literature. There is a common view that transition phenomena can be complex, with multiple transitions that can take place in parallel and over differing timescales, with many factors that can affect the transition, in addition to the multiple stages of the transition process itself. ${ }^{[18,38,39]}$ Models in attempting to encapsulate all these features are complex, this often compounded by adopting a comprehensive approach to ensure best management of the transition process.

Silverman's (1982) ${ }^{[18]}$ classic model highlighted socialization as a useful mechanism for teaching effective and efficient behaviour to help individuals cope with their transitions. This suggests that social contact with individuals who have gone through the transition process can help individuals who are preparing to go through the same experience. A "role modeling" or "mentoring" perspective has been used in subsequent approaches such as that adopted by "The Adolescent Leadership Council”, North Carolina, which brings together high school participants with college mentors, all with chronic illness. ${ }^{[40]}$ It is acknowledged that this type of support during the transition process is more effective as it is provided by those having passed through similar experiences and navigated its different aspects. This provides valuable information and problem-solving techniques that are more relevant and possibly more acceptable to those undergoing the transition.

Taking a different approach, ${ }^{[38]}$ Meleis et al. provides a comprehensive and more healthcare-modelled framework. This has four components, which are: the nature of transition; the transition conditions; the patterns of responses; and finally, the healthcare or nursing interventions. Informed by 
these components of the transition process, healthcare professionals in the clinical setting can develop interventions that nurture and facilitate the transitions taking place. These transitions would likely be less stressful and less risky, hopefully nurturing the mechanisms that improve their ability to deal with transitions in the future. ${ }^{[18,20]}$

Transition periods are usually stressful and indeterminate in nature, with indefinite timing, process and outcomes perhaps compounding other patient specific factors such as financial, social, illness, or study. Therefore healthcare professionals need to understand and acknowledge the effect of the transition process on each individual, and endeavour to minimize this effect through mutually planned interventions. Effective transition services ought to provide a means of exchanging information between patients and healthcare professionals in the clinical setting ${ }^{[41-44]}$ through a comprehensive and coordinated approach, involving all professional groups in the process. ${ }^{[12]}$ The role of family and other supporting social networks are crucial elements of the transition service. ${ }^{[11,45,46]}$ More strategically there is a need to train and continuously develop healthcare professionals especially on issues related to communication to be more explicit on care required during transition. ${ }^{[41,47,48]}$

\section{Conclusion}

It is acknowledged throughout existing literature that successful transitioning can be achieved. How to 'transition' can in some ways be considered a transferrable skill, a skill for living that we all acquire at some point as we journey through our lives. Perhaps the difficulties that some face in transitioning, is that they have not fully learned this skill, or unfortunately have maturational or health challenges that increase its level of difficulty. These individuals can be helped by others acting as role models, or by mentoring. ${ }^{[40]}$ Such supportive, person-oriented approaches have been shown to facilitate the transition process and it is perhaps worth considering some aspects of mentorship theory to understand why. Darling (1984) ${ }^{[49]}$ proposed that effective mentoring is striking a balance between providing "support" and of fering "challenge" in a dynamic relationship between mentor and mentee. In mentoring and arguably in the context of transitioning, too much support could be seen as being as detrimental (inhibiting growth and producing stasis) as would too much challenge (creating anxiety and inhibiting role performance). If mentoring is used as a conceptual framework for analyzing support for the transition process, therefore, it should be expected that it requires experience and knowledge and a favorable psychological environment and can sometimes be problematic. One could also argue that being exposed to regular transitioning produces individuals better able to cope with its pressures. Thus the biggest challenge in transitioning from pediatric to adult services, for example may not necessarily be because the individual is undergoing a metamorphosis -although this certainly requires the acquisition of developmental competencies ${ }^{[39]}$ - but because the pediatric environment, experienced from birth to 16 years, may have been over-supportive, and shielded the child from 'challenge', inadvertently inhibiting the development of transitioning skills. Logically, one would want to develop transitioning skills at an earlier age, perhaps through staged progress through the healthcare system from child to adult, in order that the enormous shock of transitioning to adult care can be minimized.

Given the growing complexity and heightened awareness of transition in healthcare it is timely that this article has examined it in its context and in some detail. It is clear from the work being done in the field that there are implications not only for professional practice, but also for the organsisation of healthcare, for research, and for curricula underpinning educational programmes. Improving the quality of different aspects of healthcare in isolation has traditionally improved the quality of experience for service users, but this is self limiting and as care moves towards a seamless, more integrated approach through for example team-based care ${ }^{[12]}$ it is evidently time to focus on the quality of transitioning from one part of the service to another, through the development of minimum standards. In time best practice in managing these difficult, and at times stressful transitions will be informed by evidence from research which ought to filter through to more appropriate models of care, policies, guidelines and pathways.

\section{CONFLiCtS OF INTEREST Disclosure}

The authors declare that there is no conflict of interest statement.

\section{REFERENCES}

[1] Kralik D, Visentin K, Van Loon A. Transition: a literature review. Journal of Advanced Nursing. 2006; 55(3): 320-329. PMid:16866826 http://dx.doi.org/10.1111/j.1365-2648.2006.03899.x
[2] Meleis A. Transitions Theory: Middle-range and situational-specific theories in nursing research and practice. Spring Publishing, New York, 2010.

[3] Berube KM, Fothergill-Bourbonnais F, Thomas M, et al. Parents' 
Experience of the Transition with their Child from a Pediatric Intensive Care Unit (PICU) to the Hospital Ward: Searching for Comfort Across Transitions. Journal of Pediatric Nursing. 2014; 586595. PMid:25023951 http://dx. doi . org/10.1016/j.pedn. 20 14.06 .001

[4] Chick N, Meleis AI. Transitions: A nursing concern. In Chinn, P. L. (Ed.) Nursing research methodology: Issues and implementation. Rockville, MD: Aspen, 1986.

[5] Meleis AI. Theoretical nursing: Development and progress.2nd ed. Philadelphia. J.B. Lippincott, 1991.

[6] Blum RWM, Garell D, Hodgman CH, et al. Transition from childcentered to adult health-care systems for adolescents with chronic conditions: A position paper of the Society for Adolescent Medicine. Journal of Adolescent Health. 1993; 14(7); 570-576. http://dx.d oi .org/10.1016/1054-139X (93) 90143-D

[7] McDonagh JE. Growing up and moving on: transition from pediatric to adult care. Pediatric Transplantation. 2005; 9(3): 36472. PMid:15910395 http://dx.doi.org/10.1111/j.1399-3 $046.2004 .00287 . \mathrm{x}$

[8] Al-Yateem N. Child to Adult: Transitional care for young adults with Cystic Fibrosis (CF). British Journal of Nursing. 2012; 21(14): 850-854. PMid:23252167 http://dx.doi.org/10.12968/bjon .2012 .21 .14 .850

[9] Frech A. Pathways to adulthood and changes in health-promoting behaviors. Advances in Life Course Research. 2014; 19: 4049. PMid:24796877 http://dx.doi.org/10.1016/j.alcr. 20 13.12 .002

[10] Annunziato R, Baisley MC, Arrato N, et al. Strangers headed to a strange land a pilot study of using a transition coordinator to improve transfer from pediatric to adult services. Journal of Pediatrics. 2013; 163: 1628-1633. PMid:23993138 http://dx.doi.org/10.1016 /j.jpeds.2013.07.031

[11] Brooten D, Naylor MD, York R, et al. Lessons learned from testing the quality cost model of Advanced Practice Nursing (APN) transitional care. Journal of Nursing Scholarship: An Official Publication of Sigma Theta Tau International Honor Society of Nursing/Sigma Theta Tau. 2002; 34(4): 369-375. http://dx.doi.org/10.1111 $/ j .1547-5069.2002 .00369 . x$

[12] Sharma N, O'Hare K, Antonelli RC, et al. Transition care: Future directions in education, health policy, and outcomes research. Academic Pediatrics. 2014; 14(2): 120-127. PMid:24602574 http: //dx.doi.org/10.1016/j.acap.2013.11.007

[13] "Transition noun" The Oxford Dictionary of English (revised edition). Ed. Catherine Soanes and Angus Stevenson. Oxford University Press, 2005. Oxford Reference Online. Oxford University Press. National University of Ireland Galway. 16 May 2010

[14] Webster dictionary, 1993 Merriam-Webster. Available from: http://gateway . proquest. com/openurl/openurl?ctx _ver=Z39.88-2003\&xri :pqil:res_ver=0.2\&res_id=xri: ilcs\&rft_id=xri:ilcs:ft: websters:Z201102713:2We

[15] Gennep A. The rites of passage. Chicago: University of Chicago; 1960.

[16] Parkes CM. Psycho-social transitions: A field for study. Social Science \& Medicine. 1971; 5: 101-115. http://dx.doi.org/10.10 16/0037-7856 (71) 90091-6

[17] Bridges W. Transitions: making sense of life's changes, Reading. MA: Addison-Wesley, 1980.

[18] Silverman P. Transitions and models of the interventions. Annals of the American Academy of Political and Social Science. 1982; 464: 174-187.

Published by Sciedu Press
[19] Bridges W. Managing organizational transitions. Organizational Dynamics. 1986; 14: 24-33. http://dx.doi.org/10.1016/0090-2 616 (86) 90023-9

[20] Schumacher KL, Meleis A. Transitions: a central concept in nursing. Journal of Nursing Scholarship. 1994; 26(2): 119-27. http: //dx.doi.org/10.1111/j.1547-5069.1994.tb00929.x

[21] Adlersberg M, Thorne S. Emerging from the chrysalis: Older widows in transition. Journal of Gerontological Nursing. 1990; 16(1): 4-8 PMid:2299132 http://dx.doi .org/10.3928/0098-9134-199 00101-03

[22] Molter B, Abrahamson K. Self-efficacy, Transition and Patient Outcomes in the Sickle Cell Disease Population. Pain Management Nursing; Elsevier Press. 2014.

[23] Kenner C, Lott JW. Parent transition after discharge from the NICU. Neonatal Network. 1990; 9(2): 31-37. PMid:2392114

[24] Ladden $M$. The impact of preterm birth on the family and society. Part 2: Transition to home. Pediatric Nursing. 1990; 16: 620-622, 626. PMid:2082282

[25] Wong DL. Transition from hospital to home for children with complex medical care. Journal of Pediatric Oncology Nursing. 1991; 8 : 3-9. http://dx.doi.org/10.1177/104345429100800102

[26] Howard-Glenn L. Transition to home: Discharge planning for the oxygen-dependent infant with bronchopulmonary dysplasia. Journal of Perinatal and Neonatal Nursing. 1992; 6(2): 85-94. http: //dx.doi.org/10.1097/00005237-199209000-00009

[27] Imle MA. Third trimester concerns of expectant parents in transition to parenthood. Holistic Nursing Practice. 1990; 4(3): 25-36. http://dx.doi.org/10.1097/00004650-199005000-00006

[28] Johnson MA, Morton MK, Knox SM. The transition to a nursing home: Meeting the family's needs. Family members face their own transition when a loved one enters a nursing home. Geriatric Nursing 1992; 13: 299-302. http://dx.doi.org/10.1016/S0197-457 2 (05) 80373-8

[29] Kerfoot K, Serafin-Dickson F, Green S. Managing transition: Resigning with style from the nurse manager position. Nursing Economics. 1988; 6: 200-202. PMid:3405325

[30] Somerville J. Near misses and disasters in the treatment of grown-up congenital heart patients. Journal of the Royal Society of Medicine. 1997; 90: 124-127. PMid:9135607

[31] Watson AR. Non-compliance and transfer from paediatric to adult transplant unit. Pediatric Nephrology. 2000; 14(6): 469-72. http: //dx.doi.org/10.1007/s004670050794

[32] Kipps S, Bahu T, Ong K, et al. Current methods of transfer of young people with Type 1 diabetes to adult services. Diabetic Medicine. 2002; 19(8): 649-54. http://dx.doi.org/10.1046/j.1464-5 $491.2002 .00757 . x$

[33] Nasr S, Campbell C, Howatt W. Transition program from pediatric to adult care for Cystic Fibrosis patients. Journal of Adolescent Health. 1992; 13(8): 682-685. http://dx.doi.org/10.1016/1054-139 $\mathrm{X}(92)$ 90063-H

[34] Cowlard J. Cystic fibrosis: transition from paediatric to adult care. Nursing Standard. 2003; 18(4): 39-41. http://dx.doi.org/10. $7748 / \mathrm{ns} 2003 \cdot 10 \cdot 18 \cdot 4 \cdot 39 \cdot c 3471$

[35] Coleman EA, Smith JD, Frank JC, et al. Preparing Patients and Caregivers to Participate in Care Delivered Across Settings: The Care Transitions Intervention. Journal of the American Geriatric Society. 2004; 52: 1817-1825. PMid:15507057 http://dx.doi.org/10. $1111 / j .1532-5415.2004 .52504 . x$

[36] LaBrie N, Kiefer K, Miettunen P, et al. Review of the success of a transition clinic for young adults with rheumatic diseases. Pediatric Rheumatology. 2008; 6(Suppl. 1): 148. http://dx.doi.org/10 1186/1546-0096-6-S1-P148 
[37] Van Walleghem N, MacDonald C, Dean HJ. Evaluation of a Systems Navigator Model for Transition From Pediatric to Adult Care for Young Adults With Type 1 Diabetes. Diabetes Care. 2008; 31(8): 1529-1530. PMid:18458141 http://dx.doi.org/10.2337/dc0 7-2247

[38] Meleis A, Sawyer L, Im E, et al. Experiencing Transitions: An Emerging Middle-Range Theory. Advances in Nursing Science. 2000; 23(1): 12-28. http://dx.doi.org/10.1097/00012272-20000 9000-00006

[39] Betz CL. Health care transition for adolescents with special healthcare needs: Where is nursing? Nursing Outlook. 2013; 61(5): 258265. PMid:23036691 http://dx.doi.org/10.1016/j.outlook .2012 .08 .009

[40] Maslow G, Adams C, Willis M, et al. An evaluation of a positive youth development program for adolescents with chronic illness. Journal of Adolescent Health. 2013; 52(2): 179-185. PMid:23332482 http://dx.doi.org/10.1016/j.jadohealth.2012.06.020

[41] Scal P. Transition for Youth with Chronic Conditions: Primary Care Physicians' Approaches. Pediatrics. 2002; 110(6): 1315-1321. PMid:12456951

[42] Nixon GM, Glazner JA, Martin JM, et al. Female sexual health care in cystic fibrosis. Archive of Disease in Childhood. 2003; 88(3): 265-266. http://dx.doi.org/10.1136/adc.88.3.265

[43] Suris JC, Parera N. Sex, drugs and chronic illness: health behaviours among chronically ill youth. European Journal of Public Health.
2005; 15(5): 484-488. PMid:16162596 http://dx.doi.org/10. 1093/eurpub/cki001

[44] Suris JC, Michaud PA, Viner RM. The adolescent with a chronic condition. Part 1: developmental issues. Archives of Disease in Childhood. 2004; 89; 938-942. PMid:15383438 http://dx.doi.org/1 $0.1136 /$ adc .2003 .045369

[45] Shaw K, Southwood T, McDonagh J. User Perspective of Transitional Care for Adolescents with Juvenile Idiopathic arthritis. Rheumatology. 2004; 43(6): 770-8. PMid:15039498 http://dx.doi.org/1 $0.1093 /$ rheumatology/keh175

[46] Reiss JG, Gibson RW, Walker LR. Health care transition: youth, family, and provider perspectives. Pediatrics. 2005; 115(1): 112-20. PMid: 15629990

[47] McDonagh JE, Southwood TR, Shaw KL, et al. Unmet education and training needs of rheumatology health professionals in adolescent health and transitional care. Rheumatology. 2004; 43: 737743. PMid:14997008 http://dx.doi.org/10.1093/rheumatol ogy/keh163

[48] McDonagh JE, Minnaar G, Kelly KM, et al. Unmet education and training needs in adolescent health of health professionals in a UK children's hospital. ActaPaediatrica. 2006; 95: 715-719.

[49] Darling LAW. What do Nurses Want in a Mentor? Journal of Nursing Administration. 1984; 14(10): 42-44. http://dx.doi.org/10.10 97/00005110-198410000-00009 